\title{
Will Curtains Come Down for the Sustainable Theatre - Evaluating Growth Challenges from an Island Nation
}

\author{
Seck $\operatorname{Tan}^{1}$
}

\begin{abstract}
Sustainable development (as defined by The Brundtland Report, 1987) points to development that meets the needs of the present without compromising the ability of future generations to meet their own. However, sustainable development denotes different perspectives to different audience; and for development to be truly sustainable, growth must be inclusive and demands equal attention to the tri-nexus of economy, society and the environment. Unfortunately, this is far from reality. In an effort to continue growing, economies pedestalize economic progress where attention is skewed towards economic performance with an intentional disregard of the environment and to the degradation of the environment. For the purpose of this paper, sustainable development focuses on debates between the twin-nexus of economy and the environment. This paper highlights sustainable development challenges for Singapore (an island nation). While most studies centered on Singapore's miraculous growth, few have examined the island's use of its environmental capital for economic growth. Island economies face similar development challenges like most global economies; the difference lies in their natural endowments (or the lack of). This underlines the need for policies to advance ecosystem preservation in land-scarce Singapore. With the use of a simple environmental valuation framework, it is demonstrated that the island nation has not fared too badly in protecting its environmental capital.
\end{abstract}

Keywords: Ecosystem, Environmental Capital, Island Nation, Singapore, Sustainable Development

\section{Introduction}

Growth is expanding the community with natural endowments such as, land and other resources towards a better standard of living via improved economic performance. Conversely, development is enhancing livability for instance, culture and heritage, education, employment, safety, and community development. Natural endowments are finite resources. Once a resource contributes to growth, it cannot be utilized for another purpose. Therefore, growth cannot be sustainable. It is development that is sustainable. The Brundtland Report defines sustainable development as, development that meets the needs of the present without compromising the ability of future generations to meet their own needs (Brundtland et al., 1987).

For development to be truly sustainable, there must be inclusive growth with equal emphasis to the tri-nexus of economy, the environment and society. To continue growing, economies pedestalize economic progress where attention is skewed towards economic performance with an intentional denial of the environment. Economic growth has resulted in an environmental crisis and in response to the crisis, unconventional models of development (Dzeraviaha, 2018) have gained acceptance in explaining sustainable development. Notwithstanding, various modes of development must remain faithful to nature as it has been well documented that nature is capital [see Daly (1991, 1996, 2005, 2007)]; an essential component of economic growth. 
An economy utilizes available resources to grow; traditional theories of economic growth present these resources as factors of production in the form of physical and human capital. But growth is not purely attributed to the two identified capitals. The environment must also be accounted because an economy remains a subset of the ecosystem. Thus, the service rendered by the ecosystem cannot be neglected as it contributes to economic growth. For development to be sustainable, economies must consider maintaining and protecting the ecosystem - herein lies the close-knit relationship between economy and the environment. And it is this relationship which forms the focal argument of this paper that is, sustainable development must balance the debates between the twin-nexus of economy and the environment.

\subsection{Island Nations}

A healthy ecosystem is a pre-requisite for sustainable development of an economy and hence, the protection and preservation of the ecosystem is critical towards a sound and functional economy. Island nations are resource deficient and vulnerable to external shocks, the sustainability predicament requires an appreciation for the ecosystem and an acknowledgment of the role it plays in economic development. Further, sustainable development is distinct in an island setting due to an island's limited growth options. Sustainable development challenges have plagued small island nations (Kerr, 2005 and Douglas, 2006). This paper makes advancement on the work that Kerr (2005) and Douglas (2006) had developed for small island nations on sustainable development. Sustainability challenges can be pressing to island nations (Deschenes and Chertow, 2004) as they are geographically isolated and with limited natural resources. Studies of sustainability on islands have suggested that regional support (Bass and Dalal-Clayton, 1995; and Wallner et al., 1996) in particular, kin relationships and cooperative development efforts (van der Velde et al., 2007) are essential ingredients towards sustainable development. Island nations are confronted with environmental consequences from the utilization of fragile natural resources for economic development (van der Velde et al., 2007). Nevertheless, island nations continue to embrace the development challenge in a bid to grow economically and stay relevant - or simply, survive.

Growth does not discriminate between economies (that includes both land-lock and island nations, and cusp between land-lock and island nations) aspiring towards greater economic progress. However, in the process of attaining economic growth, natural capital is utilized. Relative to other economies, this is more damaging to island nations in their precarious state and context of resource scarcity. For island nations with a lack of resource endowment, urbanization is deem as an effortless way to attain economic growth - put another way, urbanization has a positive impact on economic growth (Unhabitat, 2010); but urbanization can also be detrimental to the environment (Grimmond, 2007; McCarthy, 2010).

\subsection{Uniting Sustainability and Island Nations}

Sustainability points to the ability to maintain an activity at a consistent rate over a period of time. For an economy to enjoy sustainability, it requires a consistent rate of development fueled by economic growth. To attain environmental sustainability, the 
ecosystem must not be utilized beyond its rate of depletion. This concept of sustainability depicts a causal framing of how environmental problems can potentially endanger the well-being of economic, ecological, and social systems (Jenkins and Bauman, 2009). The service offered by the ecosystem towards economic growth is not indefinite - which implies that sustainability of economic growth for island nations may just be faux.

In an urban context, sustainability is possible with development strategies that protects the ecosystem. But against an island context, sustainability poses a significant challenge, as small island states may not have the capacity to embrace much needed development requirements due to limitation of economies of scale and isolated locations. That is, small island developing states (SIDS) can be susceptible as they are limited in physique, restricted in bio-physical and socio-economic senses (van der Velde et al., 2007), and ecologically fragile and economically vulnerable (Ghina, 2003). Moreover, environmental issues are a priority for SIDS as a healthy environment forms the basis of all life-support systems, including that of human well-being and socio-economic development (Ghina, 2003). SIDS are "special cases" where they had been characterized by size, remoteness, insularity, and vulnerability to external shocks (UN, 2014).

However, there are deviations to the SIDS definition such as, Singapore. ${ }^{1}$ The island nation would not be aptly recognize as a SIDS "special case" towards sustainable development. Although it is physically small, it is not remote nor insular (it is geographically surrounded by ASEAN ${ }^{2}$ neighbors); and is more than vulnerable to external shocks (environment, financial and health crises $^{3}$ ). Singapore is a small island 4 but certainly more advance than a developing state. It is more advance due to its extensively city-like arrangement with continuous urbanization evolvement (gentrification). As a resource deficit island, it needs incessant urban rejuvenation because gentrification delivers economic boost, provides capacity building for future development, and serves inevitable population expansion. Hence, Singapore is more fittingly an island as well as a city-state.

This makes the paper unique in its approach to highlight urbanization strategies in an island context towards sustainable development - which is critical with climate change threat. Studies on Singapore's urbanization highlighted balancing acts between economic growth and social and political elements (Hassan, 1969), economic growth and historical and culture elements (Lee, 1996), and associated conservation and cultural (Kong, 2000) policy recommendations. Early studies on sustainable development (Ooi, 1994; Khan 1995) presented an excellent record of fast economic growth and balanced environmental management. Regrettably, the momentum of analyzing sustainable

1 Singapore is a SIDS https://sustainabledevelopment.un.org/topics/sids/list but displays deviations as discussed by the paragraph.

2 The 10 ASEAN nations include: Brunei Darussalam, Cambodia, Indonesia, Laos, Malaysia, Myanmar, Philippines, Singapore, Thailand and Vietnam.

${ }_{3}$ Respective crises are the regional South-East Asia haze (environment), 2007-08 Global Financial Crisis (financial), 2003 Severe Acute Respiratory Syndrome (SARS).

4 At independence (1965), the island had a land area of 580 square kilometres; and grew to 719 square kilometres 50 years later (2015) from land reclamation. See Department of Statistics, Singapore http://www.singstat.gov.sg/statistics/latest-data The Economist (2015) forecasted that land area will grow to 775 square kilometres by 2030 . 
development in Singapore did not advance much - a balancing act between economic growth and environmental protection was rarely voiced. At best, it was concerns on coastal development (Wong, 1998) and discussions on assessing the environmental impacts (Hesp, 1995; Tan, 2017).

This is comprehensible as growth and development takes priority for developing a growing city-state. Nevertheless, growth has already taken its toll on Singapore that is, urbanization increased flood frequency and channel degradation (Gupta, 1982), gave rise to slum formation (Ooi and Phua, 2007), and caused changes to local climate (Li et al., 2016). Relevant studies on the city-state circled around urban planning (Yeoh, 1996; Ng, 1999); urbanization and globalization (Yeoh and Chang, 2001; Chang et al., 2004), with minimal scrutiny of the environment. This paper contributes by weighing in on development policies of the island nation - with environmental protection at its core. Further, the focus on Singapore in this piece provides sustainability debate in Asia urban policies and adds a different perspective to mega cities of those presented in Chiu (2012). Following this introduction, an overview of Singapore and the island nation's policy on development are examined. This is ensued by a simple environmental valuation framework to demonstrate the island nation's effort at protecting its environmental capital. An examination of the findings will be discussed, with a brief analysis on sustainable development for the island nation concluding this paper.

\section{Area Under Study: Singapore and Development Policies}

Singapore is an island nation born out of crisis when it was forced towards independence in 1965. The Singapore government (post-independence) engages in market forces and government interventions to stabilize the small open economy. Although land and natural resources are scarce, its strategic location means that entrepôt trade (where exports and imports are channeled in and out of) became the primary source of Singapore's economic development during the formative years. The main driver of Singapore's economy progressed from a production based industry to one of service centric (although it remains the world's largest bunkering port). Entrepôt trade evolved to foreign direct investments (FDI) and export-led industries in the provision of local employment. As the industry focus shifted from labor-intensive to capital-intensive to value-added production, jobs moved upstream and created a set of valuable skillsets for the locals.

This raised the standard of living as well as quality of living (accessible and comprehensive healthcare) for the Singapore population. The success of Singapore in the first 50 years provides an opportunity to review development options for the next 50 years. In the past five decades, economic development was fueled by strong FDI and export-oriented industries. The investment climate in Singapore has been attractive for foreign investors with low corporate taxes, stable political landscape, well-regulated banking system, good fiscal health, and vast foreign exchange reserves. A tradedependent economy is not sustainable (Tang et al., 2015) and export-led growth has its limitations. Coupled with a small domestic market, there are competencies which Singapore lacks in comparison to her regional neighbors for example, Taiwan in productivity and value-creation, and Hong Kong in the financial sector. 
Sustainable development demands that the well-beings of economy, environment and society are factored towards the formulation of public policies. For Singapore to attain sustainable development, hard economic growth must be balanced with soft innovative growth so that the island nation continues to remain an attractive option for investors and migrants (source of labor force) alike. A key ingredient for this achievement is quick and nimble bureaucracy; with a true test of the success dependent on how the island nation reacts to extreme events and how they are managed (Tan and Lai, 2016). After all, such events will certainly ensure that the island nation be better prepared should similar occurrences happen in the future. Hard economic growth is a result of bureaucratic efficiency where market mechanisms are used in close coordination and integration with public policies and programs (Thomas and Lim, 2001).

To balance hard economic growth with soft innovative growth, Tan and Phang (2005) added that bureaucratic efficiency ought to be complemented by advanced market infrastructure. Sustainable development requires collective actions on hard economic and soft innovative growth; but to date, Singapore's sustainability goals appear to be of secondary importance and subsumed within the needs of urban development and economic growth (Ooi, 2005). The argument remains that Singapore is an "alternativeenergy disadvantaged country" and development policies are skewed towards the convenience of economic progress. Justification to this argument is attributed to economics and regulation. To the first justification, economics. Evaluating Singapore's environmental policy has been broadly based on reassessing renewables' costeffectiveness (Hamilton-Hart, 2006) which alludes that economics precedes environmental impacts.

The second justification refers to regulation involving the use of Environmental Impact Assessments (EIA). Although its use in Singapore may inconvenience the promotion of physical development (Chua, 2005) and economic growth, EIA has gained traction of late (Tan, 2017). To further this traction, an option is to complement EIA with strategic environmental assessment (SEA) where cumulative impacts of multiple developments are considered. Even though Hong Kong and Taiwan have dissimilar approaches to environmental policies, both countries have utilized SEA (Victor and Agamuthu, 2014) in conjunction with public policy to good effects. As an island nation in the fight for environmental protection, Singapore may emulate the success of its neighbors by considering EIA and SEA when formulating environmental policies and be a policy setter for environmental stewardship ${ }^{5}$.

Uncertainties remain on how existing living standards can be maintained whilst development takes place with an improvement in environmental degradation and negative externalities. To date, Singapore's environmental policies ${ }^{6}$ aim to boost efficiency of resource utilization; enhance a green eco-urban environment; and engage community on capacity building. Different sectors demand different initiatives in enabling a holistic approach for development, examples include: 1. Incineration of sludge

${ }^{5}$ For instance, Australia has the Environment Protection and Biodiversity Conservation (EPBC) Act with a primary objective of protecting the environment from development risks by requiring a comprehensive evaluation of project impacts on the environment to be conducted.

${ }_{6}^{6}$ The 2015 Sustainable Singapore Blueprint, http://www.mewr.gov.sg/ssb/ 
as opposed to plastic incineration for waste management; 2. Utilization of renewables as sources of power generation; 3. Energy performance standards for household electrical appliances; 4. Carbon emissions-based vehicle scheme for automobiles; 5. Legislation for all buildings to be subjected to audits and reporting which encourages innovative building design; 6. Grants available for the development of energy efficient technologies. Given its fair share of debates, sustainable development is not easy to define, let alone being the strategic focus for protecting the environment. And believers and supporters of sustainable development interpret it in very different manners. Henceforth, it is hoped that a quantitative approach will reduce the tension across different subjects - for numbers are comprehensive and universal. The next section presents a simple environmental valuation framework to demonstrate the island nation's effort at protecting its environmental capital.

\section{Methodology: Simple Environmental Valuation Framework}

A significant aspect of sustainable development studies is to incorporate the value of ecosystem in determining how an economy has performed. This framework hinges from a consumption perspective with carbon dioxide $\left(\mathrm{CO}_{2}\right)$ as a proxy for environmental degradation with associated costing from the literature. Depreciation of the environment proxy by carbon emissions is at a cost of USD100 per ton. [See Stern (2007), Ackerman et al. (2009), Hope (2011), and Karstad (2012)]. A consumption (equivalent to expenditure) framework of an economy comprises of consumption (households), investment (firms), government spending, and exports and imports. These aggregates to the income of the economy. It is assumed that environmental depreciation is a linear proportion of income with two levels of income (standard and revised). [See Tan (2015) and please refer to the Appendix for detailed derivation of the algebra].

The Singapore economy is operationalize with a simple time-series illustration to show its environmental degradation and differing paths of economic progression.

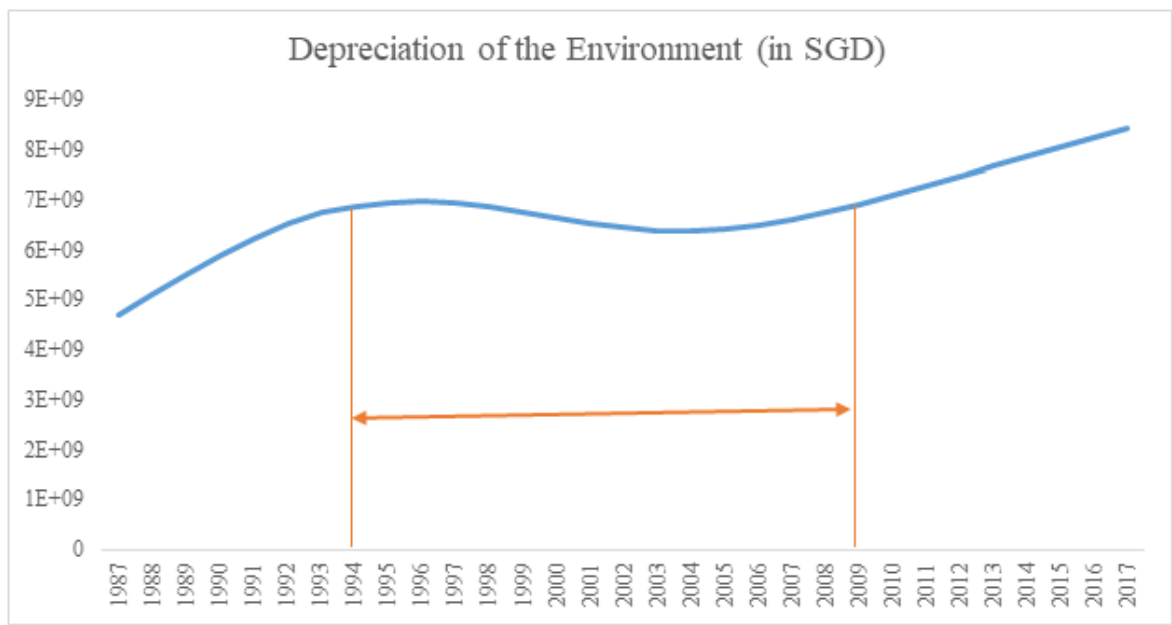

Figure 1: Singapore Depreciation of the Environment in 2010 Constant Singapore Dollar

Data Source: World Development Indicators, 2018 
Figure 1 demonstrates that over a period of 15 years (1994-2009), the environment is degrading at a moderate rate; however, the general observed trend for environmental depreciation is rising and remains scarce towards end of observed period.

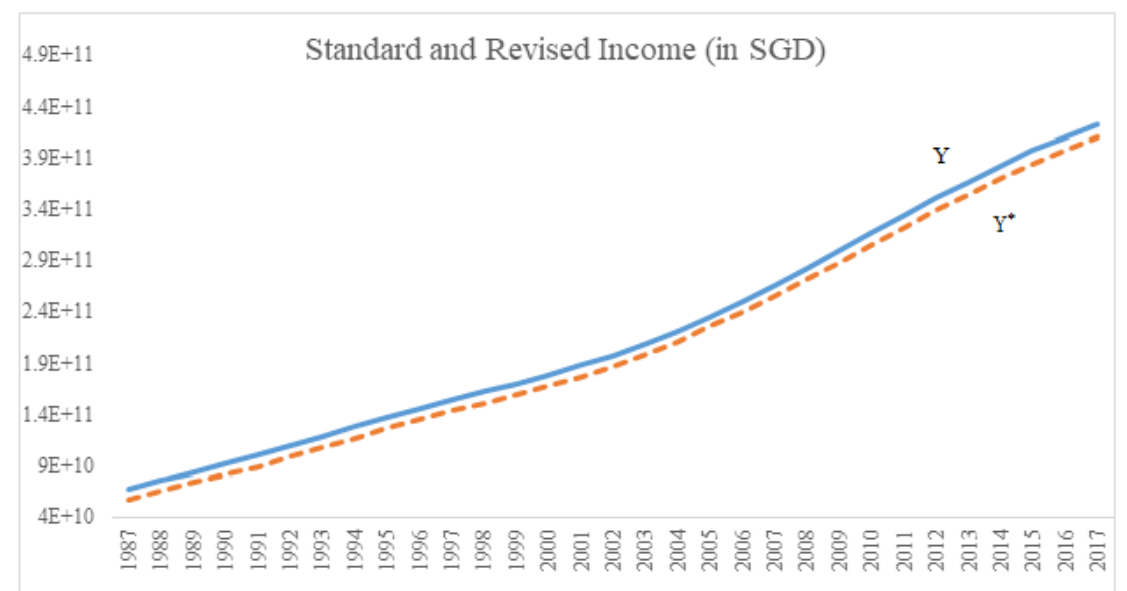

Figure 2: Standard Framework $(Y)$ and Revised (Sustainable) Framework $\left(Y^{*}\right)$

Data Source: World Development Indicators, 2018

The divergence between standard income (solid) and revised income (dotted) is minimal which suggests an effective development model; though, income is clearly overstated when environment is not taken into account.

\section{Conclusion}

This paper explores the concept of sustainable development with particular emphasis on economic growth within an ecosystem domain, and associated development policy options applied to an island nation. The misconstrued concept of sustainable growth is refined and restored to the rightful concept of sustainable development. This concept is applied to precarious island nations who must develop with an appreciation that growth is rendered by a service from the ecosystem. Sustainable studies have been conducted on economies, on mega cities and city states. But few studies have been undertaken for city states who are also island nations. Singapore is subscribed as a small island developing state; though it is more appropriately defined as both an island and a city-state that is, an island city state.

There are two interesting explanations for using Singapore as an illustration. One, it offers a deviation to the definition of small island developing states where it is not isolated (in proximity to ASEAN neighbors) and had undergone continuous urbanization (as a growth option). Two, dated studies of the island nation had revolved around urban planning; urbanization and globalization; and urban regeneration, with minimal scrutiny of the environment. Such a study will be of interest to matured cities at a juncture of reviewing their urbanization strategies with sustainability in cognizance. Any updated urban development analyses of island nations must offer due recognition to the environment for 
instance, slower economic growth or increase growth at a sensible pace.

The environmental valuation framework indicates that Singapore's environmental capital has undergone moderate depreciation. This further translates to minimal divergence between standard and revised income levels, though income is clearly inflated with no consideration for the environment. Being a resource scarce economy, the island nation requires incessant urban rejuvenation to deliver and enable economic progress. Nonetheless, a strategy of this nature must understand that the ecosystem is central. Hence, there should be no debates on preserving and protecting the ecosystem. The implication on development policies is clearly on emphasizing the discourse on sustainable development. For now, it appears that the curtains are staying up for the sustainable theatre.

\section{Acknowledgements}

The author would like to thank the Editor-in-Chief, Editors, and anonymous referees for their constructive feedback. With the usual disclaimers, the author remains grateful to A. Tan and L. Ewe.

\section{References}

Ackerman, F., Stanton, E.A., DeCanio, S.J., Goodstein, E., Howarth, R.B., Norgaard, R.B., Norman, C.S., Sheeran, K.A. (2009). The Economics of 350: The Benefits and Costs of Climate Stabilization, Economics for Equity and the Environment Network.

Bass, S.C. and Dalal-Clayton, D.B. (1995). Small Island States and Sustainable Development: Strategic Issues and Experience-7755iied. IIED.

Brundtland, G., Khalid, M., Agnelli, S., Al-Athel, S., Chidzero, B., Fadika, L., Hauff, V., Lang, I., Shijun, M., de Botero, M.M. and Singh, M. (1987). Our common future $\backslash^{\prime}$ 'brundtland report $\left.{ }^{\prime}\right)$.

Chang, T.C., Huang, S. and Savage, V.R. (2004). On the waterfront: Globalization and urbanization in Singapore. Urban Geography, 25(5), pp. 413-436.

Chiu, R.L.H. (2012). Urban Sustainability and the Urban Forms of China's Leading Mega Cities: Beijing, Shanghai and Guangzhou. Urban Policy and Research, 30(4), pp. 359-383.

Chua, B.H. (2005). Liberalization without democratization: Singapore in the next decade. In: Loh, F.K.W, Ojendal, J., eds., Southeast Asian responses to globalization: restructuring governance and deepening democracy, NIAS, pp. 57-82.

Daly, H.E. (1991). Towards an Environmental Macroeconomics. Land Economics, 67(2), pp. 255-259.

Daly, H.E. (1996). Beyond Growth, Beacon Press, Boston, United States of America.

Daly, H.E. (2005). Economics in a Full World. Scientific American, 293(3), pp. 100-107.

Daly, H.E. (2007). Ecological Economics and Sustainable Development, Selected Essays of Herman Daly. Edward Elgar, Cheltenham, UK, Northampton, MA, USA.

Deschenes, P.J. and Chertow, M. (2004). An island approach to industrial ecology: towards sustainability in the island context. Journal of Environmental Planning and Management, 47(2), pp. 201-217.

Douglas, C.H. (2006). Small island states and territories: sustainable development issues and strategieschallenges for changing islands in a changing world. Sustainable Development, 14(2), pp.75-80.

Dzeraviaha, I. (2018). Mainstream economics toolkit within the ecological economics framework. Ecological Economics, 148, pp.15-21.

Ghina, F. (2003). Sustainable development in small island developing states. Environment, Development and Sustainability, 5(1-2), pp.139-165.

Grimmond, S.U.E. (2007). Urbanization and global environmental change: local effects of urban warming. The Geographical Journal, 173(1), pp. 83-88.

Gupta, A. (1982). Observations on the effects of urbanization on runoff and sediment production in Singapore. Singapore Journal of Tropical Geography, 3(2), pp. 137-146. 
Hamilton-Hart, N. (2006). Singapore's Climate Change Policy: The Limits of Learning. Contemporary Southeast Asia: A Journal of International and Strategic Affairs, Vol. 28, No. 3, December 2006, pp. 363-384.

Hassan, R. (1969). Population change and urbanization in Singapore. Civilizations, pp. 169-188.

Hesp, P.A. (1995). The Environmental Impact Assessment process in Singapore with particular respect to coastal environments and the role of NGOs. Journal of Coastal Conservation, 1(2), pp. 135-144.

Hope, C.W. (2011). The Social Cost of CO2 from the PAGE09 Model, Economics, Discussion Paper 2011-39, September.

Jenkins, W. and Bauman, W. eds. (2009), Berkshire Encyclopedia of Sustainability: Vol 1. The Spirit of Sustainability, Berkshire Publishing Group.

Karstad, PI 2012, 'The Price on Carbon should Increase', Statoil Innovate Blog, 24 April.

Tan, S. (2015). Sustainable Development: An Empirical Illustration for Saudi Arabia, The Journal of Developing Areas, 49(6), pp. 517-529.

Kerr, S.A. (2005). What is small island sustainable development about?. Ocean \& Coastal Management, 48(7-8), pp. 503-524.

Khan, M.A. (1995). Sustainable development: The key concepts, issues and implications. Keynote paper given at the international sustainable development research conference, 27-29 March 1995, Manchester, UK, Sustainable Development, 3(2), pp. 63-69.

Kong, L. (2000). Cultural policy in Singapore: negotiating economic and socio-cultural agendas. Geoforum, 31(4), pp. 409-424.

Lee, S.L. (1996). Urban conservation policy and the preservation of historical and cultural heritage: The case of Singapore. Cities, 13(6), pp. 399-409.

Li, X.X., Koh, T.Y., Panda, J. and Norford, L.K. (2016). Impact of urbanization patterns on the local climate of a tropical city, Singapore: An ensemble study. Journal of Geophysical Research: Atmospheres, 121(9), pp. 4386-4403.

McCarthy, M.P., Best, M.J., \& Betts, R.A. (2010). Climate change in cities due to global warming and urban effects. Geophysical Research Letters, 37(9), pp. 1-5.

Ooi, G.L. (1994). A centralized approach to environmental management. The case of Singapore. Sustainable Development, 2(1), pp. 17-22.

Ooi, G.L. (2005). Sustainability and Cities: Concept and Assessment, Institute of Policy Studies and World Scientific Publishing.

Ooi, G.L. and Phua, K.H. (2007). Urbanization and slum formation. Journal of Urban Health, 84(1), pp. 27-34.

Stern, N. (2007). The Economics of Climate Change: The Stern Review, Cambridge University Press, UK.

Tan, K.S. and Phang, S.Y. (2005). From Efficiency-Driven to Innovation-Driven Economic Growth: Perspectives from Singapore. World Bank. Policy Research Working Paper 3569, April 2005.

Tan, S. (2017). Strategy for Environmental Sustainability for Island-State Singapore - Engaging the Public. Asian Journal of Public Affairs, 9(2), pp. 1-18.

Tan, S. and Lai, A. (2016). Economic Repercussions of Extreme Events for an Island Nation: Case of Singapore. The Singapore Economic Review, 61(1), pp. 1-19.

Tang, C.F., Lai, Y.W., Ozturk, I. (2015). How stable is the export-led growth hypothesis? Evidence from Asia's Four Little Dragons. Economic Modelling, 44, pp. 229-235.

United Nations (UN), (2014). Trends in Sustainable Development Small Island Developing States (SIDS). New York.

Un-habitat. (2010). State of the world's cities 2010/2011: bridging the urban divide. EarthScan.

van der Velde, M., Green, S.R., Vanclooster, M. and Clothier, B.E. (2007). Sustainable development in small island developing states: Agricultural intensification, economic development, and freshwater resources management on the coral atoll of Tongatapu. Ecological Economics, 61(2-3), pp. 456-468.

Wallner, H.P., Narodoslawsky, M. and Moser, F. (1996). Islands of sustainability: a bottom-up approach towards sustainable development. Environment and Planning A, 28(10), pp.1763-1778.

Wong, P.P. (1998). Coastal tourism development in Southeast Asia: relevance and lessons for coastal zone management. Ocean \& Coastal Management, 38(2), pp. 89-109.

Yeoh, S.A.B. (1996). Contesting space: Power relations and the urban built environment in colonial Singapore. Oxford University Press.

Yeoh, B.S. and Chang, T.C. (2001). Globalizing Singapore: debating transnational flows in the city. Urban Studies, 38(7), pp. 1025-1044. 


\section{Appendix: A Simple Keynesian Aggregate Expenditure Framework}

The following analysis is based on a simple Keynesian framework where aggregate income $(\mathrm{Y})$ is determined by aggregate expenditure. Aggregate expenditure is limited to GDP where the sum of government expenditure $(\mathrm{G})$ and net exports $(\mathrm{NX})$ are constant (denoted by $\Phi$ ) barring consumption (C) and investment (I) during a given time period. The methodology employed relies on the analytics of point estimates.

The assumed functional definitions of $\mathrm{C}$ and $\mathrm{I}$ are:

$$
\begin{aligned}
& \mathrm{C}=\alpha+\beta \mathrm{Y} \\
& I=\bar{I}+\delta Y
\end{aligned}
$$

In (1), $\alpha$ and $\beta$ represent autonomous consumption and marginal propensity to consume. By assuming $\alpha=0$, the point estimate value of $\beta$ is $\left(\frac{C}{Y}\right)$. In (2), $\overline{\mathrm{I}}$ represents fixed investment which is assumed to be contained in $\Phi$ such that $(\Phi=\overline{\mathbf{I}}+\mathrm{G}+\mathrm{NX})$ and point estimate values of $\delta$ (propensity to invest) are defined as $\left(\frac{I-\bar{I}}{Y}\right)$.

A simple definition for the equilibrating value of $\mathrm{Y}$ within standard framework based on $\mathrm{Y} \equiv$ GDP is given by:

$\mathrm{Y}^{*}=\frac{\Phi}{[1-\beta-\delta]}$

For the sustainable framework, equilibrium for income determination is redefined as ( $\mathrm{Y} \equiv \mathrm{GDP}-$ $D_{K N}$ ), where $D_{K N}$ is the depreciation of environmental capital $(K N)$. In a simple Keynesian framework, KN can be afforded a similar measurement to manufactured capital (KM), analogous to that of an income-bearing asset. That is, $\mathrm{KN}$ will undergo the same depreciation treatment as $\mathrm{KM}$ to account for the loss in its ability to generate future income. If the depreciation of environmental capital $\left(\mathrm{D}_{\mathrm{KN}}\right)$ is a simple linear proportion $\gamma$ of GDP, it follows that $\gamma$ is defined as:

$\gamma=\frac{\mathrm{D}_{\mathrm{KN}}}{\mathrm{GDP}}$

With the consideration of $\gamma$, the revised equilibrating value of income $\mathrm{Y}^{* *}$ will be:

$$
\mathrm{Y}^{* *}=\frac{\Phi(1-\gamma)}{[1-(1-\gamma)(\beta+\delta)]}
$$

In the first instance, point estimates for $\Phi, \beta, \delta$ and $\gamma$ from 1987 to 2017 are obtained. The data required to measure $\mathrm{Y}^{*}$ and $\mathrm{Y}^{* *}$ [Consumption (C), investment (I), and depreciation of environmental capital $\left.\left(\mathrm{D}_{\mathrm{KN}}\right)\right]$ have been smoothed by the Hodrick-Prescott (HP) filter. This allows the separation of business cycles from actual data and ensures that the time series is smoothed and less sensitive to short-term fluctuations but more sensitive to long-term fluctuations.

For illustrative convenience, the analysis of $\mathrm{KN}$ is confined to the depreciation of the air shed in terms of air pollution from $\mathrm{CO}_{2}$ emissions; consequently, the value of $\mathrm{D}_{\mathrm{KN}}$ is restricted to the cost of $\mathrm{CO}_{2}$ abatement. The use of $\mathrm{CO}_{2}$ is preferred as it is uncomplicated with reliable time series data. The greenhouse gases include $\mathrm{CO}_{2}$, methane $\left(\mathrm{CH}_{4}\right)$, nitrous oxide $\left(\mathrm{N}_{2} \mathrm{O}\right)$, and other greenhouse gases (GHG) [which includes hydrofluorocarbons (HFC), perfluorinated compounds (PFC), sulphur hexaflourinated compounds (PFC) and sulphur hexafluoride $\left.\left(\mathrm{SF}_{6}\right)\right]$. 